А. Е. Янтранов, Н. И. Атанов, Д. А. Цыремпилов, В. С. Потаев. Факторы «новой экономической географии» и интеграционнная деятельность регионов Забайкалья

УДК 332.14

DOI 10.18101/2304-4446-2019-2-91-97

\title{
ФАКТОРЫ «НОВОЙ ЭКОНОМИЧЕСКОЙ ГЕОГРАФИИ» И ИНТЕГРАЦИОНННАЯ ДЕЯТЕЛЬНОСТЬ РЕГИОНОВ ЗАБАЙКАЛЬЯ
}

\section{(C) Янтранов Александр Евгеньевич}

кандидат экономических наук, заведующий лабораторией региональной экономики Научно-исследовательского центра ИЭУ, Бурятский государственный университет имени Доржи Банзарова Россия, 670000, г. Улан-Удэ, ул. Смолина, 24а

E-mail: yantran@mail.ru

\section{(C) Атанов Николай Иванович}

доктор экономических наук, ведущий научный сотрудник Научно-исследовательского центра ИЭУ,

Бурятский государственный университет имени Доржи Банзарова, Россия, 670000, г. Улан-Удэ, ул. Смолина, 24а

E-mail: ni.atanov@yandex.ru

\section{(C) Цыремпилов Даши Анатольевич}

кандидат экономических наук, доцент, Восточно-Сибирский государственный университет технологий и управления Россия, 670013, г. Улан-Удэ, ул. Ключевская, 40В

E-mail: tsyrempilov-dashi@yandex.ru

\section{(C) Потаев Виктор Сергеевич}

доктор экономических наук, профессор ИЭУ,

Бурятский государственный университет имени Доржи Банзарова

Россия, 670000, г. Улан-Удэ, ул. Смолина, 24а

E-mail: potaev_viktor@mail.ru

С учетом сложной экономической ситуации в России и на фоне усиления геополитической напряженности требуется проведение мер региональной политики, направленных на использование внутреннего потенциала территорий за счет межрегиональной кооперации и интеграции, раскрытия так называемых факторов развития «новой экономической географии» с использованием институтов территориального развития нового типа. Для регионов Забайкалья дана общая характеристика факторов природных ресурсов, географического положения, агломерационных эффектов, институтов. В статье систематизирована информация по теме и представлено видение развития регионов Забайкалья с использованием раскрытия потенциала факторов «новой экономической географии» при помощи реализации проектов двух уровней. Первый уровень характеризуется прямым участием Минвостокразвития РФ в реализации проектов, второй - прямым участием регионов с курированием проектов со стороны министерства.

Ключевые слова: стратегия развития; зеленая экономика; региональные институты развития; институты; региональная экономика; устойчивое развитие.

Статья выполнена в рамках поддержки Бурятским государственным университетом им. Д. Банзарова грантового проекта № 19-17-0502 


\section{Для цитирования:}

Факторы «новой экономической географии» и интеграционнная деятельность регионов Забайкалья / А. Е. Янтранов [и др.] // Вестник Бурятского государственного университета. Экономика и менеджмент. 2019. № 2. С. 91-97.

Введение. С учетом стагнации экономики России на фоне усиления геополитической напряженности требуется проведение активной региональной политики, направленной на использование внутреннего потенциала территорий на основе межрегиональной интеграции, раскрытия так называемых факторов развития «новой экономической географии».

Необходимо отметить, что законодательная основа для межрегионального стратегического взаимодействия имеется и прежде всего это Федеральный закон от 28 июня 2014 г. № 172-Ф3 «О стратегическом планировании в Российской Федерации», Государственная программа «Социально-экономическое развитие Дальнего Востока и Байкальского региона», утвержденная постановлением Правительства от 15 апреля 2014 года № 308.

Отдельно стоит отметить наличие общей институциональной оболочки в форме федерального округа и административного аппарата федерального уровня, такого как Министерство Российской Федерации по развитию Дальнего Востока и Арктики с набором подведомственных учреждений и институтов развития.

\section{Факторы «новой экономической географии»}

Фактор агломерационного эффекта. Регионы Забайкалья характеризуются чрезвычайно низкой плотностью населения: в Республике Бурятия - 2,8 чел/км², в Забайкальском крае $-2,47$ чел/ $\mathrm{m}^{2}$, что намного ниже среднего значения по РФ в 8,57 чел/км². При этом показатель урбанизации как соотношение городского населения к общему в 2018 г. составил по Республике Бурятия - 59\% (72-е место среди регионов России), по Забайкальскому краю - 68,2\% (51-е место) ${ }^{1}$.

Потенциал использования агломерационного эффекта сконцентрирован лишь в административных центрах регионов, где проживает основная часть населения. При этом миграционный отток из регионов не прекращается. Дальнейшее развитие бизнеса и предпринимательства ограничено размерами рынка и экономическими расстояниями (сочетание географического расстояния и различных транзакционных издержек) до основных центров развития.

\section{Фактор использования природных ресурсов}

Невозобновлямые природные ресурсы

Измеряем по ВРП раздела С. «Добыча полезных ископаемых»: Республика Бурятия и Забайкальский край находятся на 34-м (969 тыс. р. в месяц на 1 жителя) и 26-м местах (2 921 тыс. р.), что свидетельствует об умеренном использовании потенциала ${ }^{2}$. При этом стоит отметить высокие экологические риски дальнейшего освоения месторождений полезных ископаемых (например, Холоднинского колчеданно-полиметаллического месторождения, расположенного в преде-

1 Доля городского населения в общей численности населения на 1 января. URL: https://fedstat.ru/indicator/36057 (дата обращения: 10.02.2019).

${ }^{2}$ Валовой региональный продукт по отраслям экономики, в ценах 2017-го года, на душу населения в месяц. URL: https://russia.duck.consulting/maps/158/2016 (дата обращения: 10.02.2019). 
А. Е. Янтранов, Н. И. Атанов, Д. А. Цыремпилов, В. С. Потаев. Факторы «новой экономической географии» и интеграционнная деятельность регионов Забайкалья

лах Центральной экологической зоны Байкальской природной территории, где хозяйственная деятельность ограничена согласно закону «Об охране озера Байкал» в 80 км от озера Байкал и др.).

Возобновляемые природные ресурсы.

Забайкалье - территория пастбищного скотоводства. При этом поголовье скота в двух субъектах в последние годы не меняется (с 2015 по 2016 г. стабилизировалось на уровне 849 тыс. голов). И только в 2017 г. произошел прирост на 11 тыс. голов за счет роста поголовья овец и коз в Бурятии. Для сравнения: в Монголии за 2016 г. поголовье скота увеличилось на 7,5\% до 66,2 млн.

Если на одного жителя в Монголии приходится 15,9 головы скота, то в Бурятии $-0,67$, в Забайкальском крае - 0,88; на 1 км $^{2}$ территории в Монголии 31,1 , в Бурятии - 0,68, в Забайкальском крае - 0,89. То есть потенциал увеличения поголовья — кратный $[1$, с. 60$]$.

Потребность в объединении действий двух субъектов Федерации обоснована как необходимостью интенсивного развития экспортного потенциала, так и требованиями обеспечения продовольственной безопасности всего Забайкалья. В особенности на фоне опережающего роста цен на ключевые продукты питания на глобальных рынках. Экспертами отмечается долгосрочность данного тренда. В этих условиях рост цен следует принять как данность и необходимо решать насущный вопрос преодоления продовольственной зависимости [2]. Решение этого вопроса видится в интенсивном развитии отраслей специализации региона, с тем чтобы за счет экспортной и межрегиональной активности обеспечить собственные потребности товарами нерегиональной специализации.

Фактор географического местоположения регионов. Характеризуется, с одной стороны, удаленностью Забайкальского субрегиона от центров экономического роста, сконцентрированных в европейской части России (до Москвы и Санкт-Петербурга - свыше 4400 км, до Екатеринбурга - 3035 км), с другой относительной близостью к Восточной Азии (до Пекина - 1489 км, Сеула 2192 км). При этом по объему экспорта, характеризующего внешнеторговую активность, в 2016 г. Забайкальский край занимал 60-е место (215 млн долл.), Республика Бурятия - 37-е место (960 млн долл.).

Институциональные факторы. Стоит отметить сложившуюся периферийность территории как в географическом плане (самая восточная окраина Сибирского федерального округа и с 2019 г. — самая западная окраина Дальневосточного федерального округа), так и с точки зрения вовлечения в федеральные инициативы и хозяйственный оборот, что отражает остаточное внимание федерального центра, превалировавшее до недавнего времени.

По факту территория представляет собой приграничную «буферную зону» России к Китаю и Монголии, которая, с одной стороны, накладывает на регионы дополнительную нагрузку и ограничения на использование приграничных территорий в хозяйственном обороте, с другой - имеет потенциал развития трансграничной торговли.

Около $10 \%$ территории Забайкальского края и 70\% территории Республики Бурятия являются водосборной зоной озера Байкал, что обусловливает особые природоохранные ограничения и некоторые институциональные барьеры для 
хозяйственной деятельности и приводит к дополнительным издержкам для многих хозяйствующих субъектов [3, с. 128].

Оба субъекта Федерации с конца 2018 г. входят в Дальневосточный федеральный округ, и в то же время они включены активный межрегиональный товарооборот с регионами Сибирского федерального округа, продолжая оставаться членами межрегиональных ассоциаций субъектов Федерации «Сибирское соглашение» и «Дальний Восток и Забайкалье».

Отметим наличие институтов территориального развития новой формации с набором подведомственных учреждений и кураторством на уровне полномочного представителя Президента РФ в ДФО и заместителя председателя правительства РФ, что обеспечивает политические и административные возможности защиты интересов субъектов ДФО.

В условиях высоких административных барьеров в России данный фактор предопределяет успешность лоббирования интересов подведомственных территорий, с одной стороны, с другой - дает возможности снятия барьеров на уровне федерального законодательства и новые возможности международного и межрегионального сотрудничества в рамках федерального округа.

В настоящее время реализуется первичный этап интеграции регионов Забайкалья в социально-экономическое пространство Дальнего Востока. Ведомства субъектов участвуют в разработке соответствующих программных документов с определением центров экономического роста, выработке и реализации дорожных карт по основным направлениям: создание территорий опережающего развития, разработка региональных стратегий и дорожных карт по привлечению инвестиций и поддержке экспорта, внедрение и реализация программы «Дальневосточный гектар», кадровое обеспечение инвестиционных проектов с развитием системы образования и профориентации с возможным открытием новых специальностей, внедрение механизма электронных виз, включение мероприятий и объектов в «дальневосточные разделы» [4, с. 2].

Запуск проектов межрегиональной эксплуатации возможен в рамках реализации Национальной программы развития Дальнего Востока на период до 2025 г. и на перспективу до 2035 г.

Выделяются два уровня реализации проектов в зависимости от сложности преодоления административных барьеров и привлечения соответствующих ресурсов.

Первый уровень - это ключевые интеграционные проекты, требующие участия Министерства Российской Федерации по развитию Дальнего Востока и Арктики:

- для преодоления фактора низкой базы агломерационного эффекта и использования фактора географического центрического расположения:

1. Строительство транспортной инфраструктуры, повышающее межрегиональную и международную доступность и развивающее транзитный и приграничный потенциал территории.

2. Смягчение визового контроля для жителей КНР и России с использованием режима электронных виз.

3. Ускорение таможенных процедур для экспортно-импортных операций, в особенности для транзитных операций. 
А. Е. Янтранов, Н. И. Атанов, Д. А. Цыремпилов, В. С. Потаев. Факторы «новой экономической географии» и интеграционнная деятельность регионов Забайкалья

4. Расширение международного и межрегионального сотрудничества на основе разработки трансграничных туристических маршрутов с использованием режима единых транзитных туристических виз.

- для сочетания наличия природных возобновляемых ресурсов и географического расположения:

5. Развитие комплексных проектов по освоению месторождений полезных ископаемых с созданием единой энергетической базы (каскада гидроэлектростанций на р. Витим, прежде всего, Мокской ГЭС мощностью 1200 МВТ с объемом инвестиций около 150 млрд р., по оценкам Правительства РБ) с соответствующей инфраструктурой и возможностями экспорта электроэнергии совместно с энергетическими предприятиями Забайкальского края ${ }^{1}$.

Второй уровень - это проекты по экономической кооперации и интеграции Республики Бурятия и Забайкальского края, направленные на использование следующих факторов:

- наличия природных ресурсов (земельного ресурса) и географического расположения:

1. Проект формирования «мясного пояса» России на основе традиционного животноводства на принципах зеленой экономики, с дальнейшим распространением по всей зоне географической Восточной Сибири с умеренным расширением как за счет Иркутской области, Красноярского края, Республика Тыва и Хакасии, так и за счет кооперации с Монголией и АРВМ КНР. Только в Бурятии размер пастбищных и сенокосных угодий составляет 2,2 млн га, в Забайкальском крае 6,2 млн га. При этом общая площадь пастбищ и сенокосов Восточной Сибири составляет 16,3 млн га [4, с. 8].

2. Развитие бальнеологического проекта по созданию международной Байкальской здравницы с использованием минеральных лечебных источников Забайкалья: в Республике Бурятия (свыше 360), в Забайкальском крае (около 300) с дальнейшей интеграцией с проектами Монголии и Китая для развития трансграничного туризма.

3. Комплексный проект по развитию глубокой лесопереработки и экологизации лесного хозяйства с развитием экспорта саженцев.

4. Проект по развитию экспортно ориентированной акваэкономики, в основном для снабжения рынков вододефицитного Китая и других стран питьевой водой озерного качества и целебными минеральными водами. Прогнозируется рост только одного рынка бутилированной воды Китая в 2 раза за 10 лет до 45-50 млрд долл.

5. Продвижение бренда Республики Бурятия и Забайкалья в целом как территории зеленой цивилизации и донора по питьевой пресной воде и кислороду, комплементарного развитию региона [5, с. 114].

Заключение. Учитывая вхождение в Дальневосточный федеральный округ с наличием широкого набора инструментов, институтов территориального развития и, что важнее, механизмов преодоления административных барьеров федерального уровня, межрегиональная кооперация выходит на первый план.

\footnotetext{
${ }^{1}$ План действий (дорожная карта) по интеграции Республики Бурятия в экономическое пространство Дальнего Востока от 26.12.2018 АК-05/344.
} 
Большая часть обозначенных кооперационных проектов также гармонично встраивается и в совместную программу создания экономического коридора «Китай - Монголия - Россия» и использования Транссиба на Великом шелковом пути в качестве содержательного наполнения соответствующих разделов программы. При этом участие в данной программе Республики Бурятия и Забайкальского края не ограничивается только этими проектами.

Для регионов Забайкалья именно сотрудничество и кооперация являются основным механизмом развития, поскольку преодоление барьеров и использование внутренних факторов возможны только совместными усилиями.

\section{Литература}

1. Субанаков Г. Ю. Анализ приграничного сотрудничества России и Монголии (на примере Республики Бурятия) // Вестник Бурятского государственного университета. Экономика и менеджмент. 2017. № 3. С. 58-64.

2. Бжезинский Д. Шанс столетия // Профиль. 2008. 28 апр. С. 44-51

3. Атанов Н. И., Потапов Л. В., Борисов Г. О. Об интенсификации экономического взаимодействия регионов Забайкалья // Регион: экономика и социология. 2011. № 3. C. $124-138$.

4. Агроландшафты Восточной Сибири для кормопроизводства и агроэкологии / И. А. Трофимов [и др.] // Достижения науки и техники АПК. 2018. Т. 32. № 2. С. 8-11.

5. Атанов Н. И., Янтранов А. Е. Потенциал «зеленого развития» Республики Бурятия // ЭКО. 2015. № 11(497). С. 111-119.

\section{FACTORS OF "NEW ECONOMIC GEOGRAPHY" AND INTEGRATION ACTIVITIES OF TRANSBAIKAL REGIONS}

\section{Aleksandr E. Yantranov}

Cand. Sci. (Econ.), Head of the Laboratory of Regional Economy,

Dorzhi Banzarov Buryat State University

24a Smolina St., Ulan-Ude 670000, Russia

E-mail: yantran@mail.ru

\section{Nikolay I. Atanov}

Dr. Sci. (Econ.), Leading Researcher,

Dorzhi Banzarov Buryat State University

24a Smolina St., Ulan-Ude 670000, Russia

E-mail: ni.atanov@yandex.ru

\section{Dashi A. Tsyrempilov}

Cand. Sci. (Econ.), A/Prof.,

East-Siberian State University of Technology and Management

40v Klyuchevskaya St., Ulan-Ude 670013, Russia

E-mail: tsyrempilov-dashi@yandex.ru

Viktor S. Potaev

Dr. Sci. (Econ.), Prof.,

Dorzhi Banzarov Buryat State University

24a Smolina St., Ulan-Ude 670000, Russia

E-mail: potaev_viktor@mail.ru 
Taking into account the difficult economic situation in Russia and the increasing geopolitical tensions, regional policies are required to use the internal potential of the territories through interregional cooperation and integration, influence of the so-called development factors of "new economic geography" and innovative territorial development institutions. We have given a general description of such factors for Transbaikal regions: natural resources, geographical location, agglomeration effects, and institutions. The article systematized the information and presented the perspective of Transbaikal development through the potential factors of "new economic geography" using two-level projects. The first level is characterized by the direct participation of Ministry for Development of the Russian Far East in the implementation of projects, the second - by the direct participation of regions under the supervision of Ministry.

Keywords: development strategy; green economy; regional development institutions; institutions; regional economy; sustainable development. 